\title{
Nitrous oxide emissions in soils fertilized with pig manure: soil processes and strategies of control and mitigation
}

Emissões de óxido nitroso em solos adubados com dejetos suínos: processos no solo e estratégias de controle e mitigação

Emisiones de óxido nitroso en suelos fertilizados con estiércol porcino: procesos de suelo y estrategias de control y mitigación

Received: 01/27/2021 | Reviewed: 02/04/2021 | Accept: 02/06/2021 | Published: 02/14/2021

\author{
Vilmar Muller Júnior \\ ORCID: https://orcid.org/0000-0002-2908-9411 \\ Universidade Federal de Santa Catarina, Brazil \\ E-mail: vilmar.muller@ifpr.edu.br \\ Jucinei José Comin \\ ORCID: https://orcid.org/0000-0002-6176-6208 \\ Universidade Federal de Santa Catarina, Brazil \\ E-mail: j.comin@ufsc.br \\ Guilherme Wilbert Ferreira \\ ORCID: https://orcid.org/0000-0002-1768-2058 \\ Universidade Federal de Santa Catarina, Brazil \\ E-mail: guilhermewferreira@ hotmail.com \\ Jorge Manuel Rodrigues Tavares \\ ORCID: https://orcid.org/0000-0002-4222-4251 \\ Instituto Politécnico da Beja, Portugal \\ E-mail: jorge.tavares@ipbeja.ptr \\ Rafael da Rosa Couto \\ ORCID: https://orcid.org/0000-0003-1071-4165 \\ Instituto Federal Catarinense, Brazil \\ E-mail: rrccouto@hotmail.com \\ Paulo Belli Filho \\ ORCID: https://orcid.org/0000-0003-4338-2830 \\ Universidade Federal de Santa Catarina, Brazil \\ E-mail:paulo.belli@ufsc.br
}

\begin{abstract}
Nitrous oxide $\left(\mathrm{N}_{2} \mathrm{O}\right)$ is one of the main gases that contributes to the greenhouse effect. With a Global Warming Potential (GWP) 265 times greater than that of carbon dioxide $\left(\mathrm{CO}_{2}\right)$, over a 100-year horizon, $\mathrm{N}_{2} \mathrm{O}$ also has the potential for the depreciation of the ozone layer. The activities related to agriculture and livestock are responsible for approximately $60 \%$ of the global anthropogenic emissions of this gas to the atmosphere. In Brazil, the sector corresponds to $37 \%$ of total emissions. The objectives of this review article were: (i) To verify which are the main processes involved in $\mathrm{N}_{2} \mathrm{O}$ emissions in soils fertilized with swine manure; (ii) What are the direct emissions on these soils under different management systems, and; (iii) What are the possible strategies for controlling and mitigating $\mathrm{N}_{2} \mathrm{O}$ emissions. Therefore, an exploratory and qualitative research of articles was carried out using the following keywords: óxido nitroso', 'nitrous oxide', ' $\mathrm{N}_{2} \mathrm{O}$ ', 'nitrogênio', 'nitrogen', 'suínos, 'pig, 'swine', 'dejetos', 'manure' and 'slurry'. Effects of pig diet, manure treatment systems, presence of heavy metals in the soil and moisture content of manure on $\mathrm{N}_{2} \mathrm{O}$ emissions were verified. Therefore, we recommend integrated studies of the quantitative and qualitative impacts of the levels and sources of nitrogen in the animals' diets on $\mathrm{N}_{2} \mathrm{O}$ emissions after the application of these wastes to the soil. We also recommend studies related to the effects of copper and zinc contents added to the soil via swine manure on enzymes that catalyze the biotic denitrification process in the soil.
\end{abstract}

Keywords: Environmental management; $\mathrm{N}_{2} \mathrm{O}$; Greenhouse gas emissions; Organic fertilization; Microbial community.

\section{Resumo}

$\mathrm{O}$ óxido nitro $\left(\mathrm{N}_{2} \mathrm{O}\right)$ é um dos principais gases que contribuem para o efeito estufa. Com um Potencial de Aquecimento Global 265 vezes maior que o dióxido de carbono $\left(\mathrm{CO}_{2}\right)$, em um horizonte de 100 anos, também apresenta potencial de depreciação da camada de ozônio. As atividades agropecuárias são responsáveis por aproximadamente $60 \%$ das emissões antropogênicas globais deste gás. No Brasil, este setor corresponde por $37 \%$ do 
total das emissões. Os objetivos deste artigo de revisão foram: (i) Verificar quais são os principais processos envolvidos nas emissões de $\mathrm{N}_{2} \mathrm{O}$ em solos adubados com dejetos suínos; (ii) Quais são as emissões diretas nesses solos sob diferentes sistemas de manejo, e; (iii) Quais são as possíveis estratégias de controle e mitigação das emissões de $\mathrm{N}_{2} \mathrm{O}$. Para tanto, foi realizada uma pesquisa de caráter exploratório e qualitativo de artigos utilizando as seguintes palavras-chave: 'óxido nitroso', 'nitrous oxide', ' $\mathrm{N}_{2} \mathrm{O}$ ', 'nitrogênio', 'nitrogen', 'suínos, 'pig, 'swine', 'dejetos', 'manure' e 'slurry'. Foram verificados efeitos da dieta dos suínos, dos sistemas de tratamento dos dejetos, da presença de metais pesados no solo e dos teores de umidade dos dejetos nas emissões de $\mathrm{N}_{2} \mathrm{O}$. Sendo assim, recomendamos estudos integrados dos impactos quantitativos e qualitativos dos teores e fontes de nitrogênio nas dietas dos animais sobre as emissões de $\mathrm{N}_{2} \mathrm{O}$ após a aplicação desses dejetos ao solo. Também recomendamos estudos relacionados aos efeitos dos teores de cobre e zinco adicionados ao solo via dejetos de suínos sobre as enzimas que catalisam o processo de desnitrificação biótica no solo.

Palavras-chave: Gestão ambiental; $\mathrm{N}_{2} \mathrm{O}$; Emissões de gases de efeito estufa; Adubação orgânica; Comunidade microbiana.

\section{Resumen}

El óxido nitroso $\left(\mathrm{N}_{2} \mathrm{O}\right)$ es uno de los principales gases que contribuyen al efecto invernadero. Con un potencial de calentamiento global 265 veces mayor que el dióxido de carbono $\left(\mathrm{CO}_{2}\right)$, en un horizonte de 100 años, también tiene un potencial de depreciación de la capa de ozono. Las actividades agrícolas son responsables de aproximadamente el $60 \%$ de las emisiones antropogénicas globales de este gas. En Brasil, este sector representa el 37\% de las emisiones totales. Los objetivos de este artículo de revisión fueron: (i) Verificar cuáles son los principales procesos involucrados en las emisiones de $\mathrm{N}_{2} \mathrm{O}$ en suelos fertilizados con estiércol porcino; (ii) Cuáles son las emisiones directas en estos suelos bajo diferentes sistemas de manejo, y; (iii) Cuáles son las posibles estrategias para controlar y mitigar las emisiones de $\mathrm{N}_{2} \mathrm{O}$. Por lo tanto, se realizó una investigación exploratoria y cualitativa de artículos utilizando las siguientes palabras clave: óxido nitroso', 'nitrous oxide', ' $\mathrm{N}_{2} \mathrm{O}$ ', 'nitrogênio', 'nitrogen', 'suínos, 'pig, 'swine', 'dejetos', 'manure' y 'slurry'. Se verificaron los efectos de la dieta del cerdo, los sistemas de tratamiento de estiércol, la presencia de metales pesados en el suelo y el contenido de humedad del estiércol sobre las emisiones de $\mathrm{N}_{2} \mathrm{O}$. Por lo tanto, recomendamos estudios integrados de los impactos cuantitativos y cualitativos de los niveles y fuentes de nitrógeno en la dieta de los animales sobre las emisiones de $\mathrm{N}_{2} \mathrm{O}$ luego de la aplicación de estos desechos al suelo. También recomendamos estudios relacionados con los efectos del contenido de cobre y zinc agregado al suelo a través del estiércol de cerdo sobre las enzimas que catalizan el proceso de desnitrificación biótica en el suelo.

Palabras clave: Gestión ambiental; $\mathrm{N}_{2} \mathrm{O}$; Emisiones de gases de efecto invernadero; Fertilización orgânica; Comunidad microbiana.

\section{Introduction}

Nitrous oxide $\left(\mathrm{N}_{2} \mathrm{O}\right)$ is one of the main gases that contribute to the greenhouse effect. With a global warming potential (GWP) 265 times that of carbon dioxide $\left(\mathrm{CO}_{2}\right), \mathrm{N}_{2} \mathrm{O}$ also has ozone depletion potential over a 100-year time horizon (IPCC, 2013). Human activities have significantly increased global $\mathrm{N}_{2} \mathrm{O}$ emissions. The increase of $\mathrm{N}_{2} \mathrm{O}$ concentration in atmosphere affect the environmental conditions, in addition to increasing the scale of phenomena associated to climate change. An increase of $20 \%$ in $\mathrm{N}_{2} \mathrm{O}$ concentration in the atmosphere has been estimated since 1970, at a steady rate of $0.73 \pm 0.03 \mathrm{ppmv}^{\mathrm{yr}} \mathrm{r}^{-1}$ (IPCC, 2013). $\mathrm{N}_{2} \mathrm{O}$ represents $16 \%$ (7.84 $\mathrm{Gt} \mathrm{CO}_{2}-\mathrm{eq} / \mathrm{yr}^{-1}$ ) of the total greenhouse gas (GHG) emissions from 2000 to 2010 (IPCC, 2013). On a global scale, uncultivated soils account for most $\mathrm{N}_{2} \mathrm{O}$ emissions $\left(6.6 \mathrm{Tg} \mathrm{N} / \mathrm{yr}^{-1}\right)$, followed by agricultural soils (4.7 $\mathrm{Tg} \mathrm{N} / \mathrm{yr}^{-1}$ ). Agricultural soils make up $27 \%$ of total $\mathrm{N}_{2} \mathrm{O}$ emissions (Syakila and Kroeze, 2011) and 60\% of human-caused emissions (Aguilera et al., 2013). Among the largest gas-emitting countries and blocks of countries are China (18.6\%), the United States $(9.1 \%)$, the European Union (8.4\%; 28 countries), India (7.6\%) and Brazil (6.8\%), which together represent approximately $50.6 \%$ of global human emissions. In Brazil, agriculture is one of the main sectors responsible for emissions and accounts for approximately $37 \%$ of the national $\mathrm{N}_{2} \mathrm{O}$ emissions (BRASIL, 2014).

Manure from animal production represents 30 to $50 \%$ of total emissions and is among the sources that contribute to $\mathrm{N}_{2} \mathrm{O}$ emission in the agricultural sector. Table 1 shows the $\mathrm{GHG}$ emissions $\left(\mathrm{Tg} \mathrm{CO}_{2}-\mathrm{eq} / \mathrm{yr}^{-1}\right)$ from the storage and treatment of animal manure, as well as its application to the soil. 
Table 1. Greenhouse gas emissions from animal manure.

\begin{tabular}{cccc}
\hline \multirow{2}{*}{ Emission source } & \multicolumn{2}{c}{$\mathrm{Tg} \mathrm{CO}_{2}$-eq/yr ${ }^{-1}$} \\
\cline { 2 - 4 } Manure storage and treatment & World & Brazil \\
\cline { 2 - 3 } Pig manure & 91.55 & 3.54 \\
Cattle manure & 161.49 & 4.42 \\
Poultry manure & 20.99 & 0.92 \\
Others & & 77.78 & 0.63 \\
Total & 351.81 & 9.51 \\
\hline Manure aplication & in soil & & 3.19 \\
Pig manure & 34.27 & 4.80 \\
Cattle manure & 81.75 & 1.50 \\
Poultry manure & 28.76 & 1.45 \\
Others & & 47.04 & 10.94 \\
\hline
\end{tabular}

${ }^{1}$ goat, sheep, buffalo, donkey, etc. $\mathrm{Tg}=10^{12} \mathrm{~g}$. Fonte: FAO (2016).

Globally, the application of swine manure to the soil is responsible for approximately $18 \%$ of GHG emissions to the atmosphere from the use of animal manure as fertilizers. In Brazil, this practice is responsible for $29 \%$ of emissions. This high emission value can be explained by the large volume of pig manure produced daily in Brazil. In general, a pig in growingfinishing phase ( 25 to $120 \mathrm{~kg}$ body weight) produces approximately $4.5 \mathrm{~L}$ of manure per day (FATMA, 2014; Tavares et al., 2014). With an approximate herd of 35 million head of growing-finishing pigs, an estimated 158 million liters of manure are produced per day in Brazil. If the breeding sows are added to this herd, there is a total of 39.9 million head, reaching an approximate 270 million liters of manure per day.

Considering its fertilizer potential, the use of pig manure in agriculture is an alternative to the improper disposal of these materials in soil and water. It lessens environmental impacts, in addition to reducing the use of mineral fertilizers and the costs of purchase. The use of manure contributes to nutrient cycling of pig farming and increased crop yields. Pig manure is composed of nitrogen $(\mathrm{N})$, predominantly as ammonium $\left(\mathrm{N}^{-N_{4}}{ }^{+}\right)$, in addition to phosphorus $(\mathrm{P})$, potassium $(\mathrm{K})$, copper $\left(\mathrm{Cu}^{+2}\right)$, zinc $\left(\mathrm{Zn}^{+2}\right)$ (Tiecher et al., 2013) and organic carbon in soluble and particulate forms. Table 2 shows the average physical and chemical characterization of the liquid pig manure in nursery (32 production cycles, $\mathrm{n}=54,715$ piglets) and grower-finisher (33 production cycles, $\mathrm{n}=13,276$ pigs) phases (Tavares, 2016). 
Table 2. Average physical and chemical characterization of liquid pig manure (dry weight basis).

\begin{tabular}{lcccccc}
\hline \multirow{2}{*}{ Manure } & \multicolumn{3}{c}{ Nursery } & \multicolumn{3}{c}{ Grower-Finisher } \\
\cline { 2 - 7 } & Average & Max. & Min. & Average & Max. & Min. \\
\hline $\mathrm{TS}\left(\mathrm{g} \mathrm{L}^{-1}\right)$ & $40.9 \pm 20.2$ & 74.5 & 14.9 & $58.2 \pm 14.9$ & 91.8 & 33.7 \\
$\mathrm{FS}\left(\mathrm{g} \mathrm{L}^{-1}\right)$ & $9.8 \pm 3.9$ & 16.9 & 5.5 & $14.6 \pm 3.3$ & 22.1 & 9.5 \\
$\mathrm{COD}\left(\mathrm{g} \mathrm{L}^{-1}\right)$ & - & - & - & $74.8 \pm 14.9$ & 111.3 & 47.7 \\
$\mathrm{TOC}\left(\mathrm{g} \mathrm{L}^{-1}\right)$ & $17.1 \pm 9.2$ & 30.8 & 4.5 & - & - & - \\
$\mathrm{TN}\left(\mathrm{g} \mathrm{L}^{-1}\right)$ & $3.3 \pm 1.4$ & 6.2 & 1.3 & $5.3 \pm 1.1$ & 7.2 & 3.6 \\
$\mathrm{~N}-\mathrm{NH}_{4}^{+}\left(\mathrm{g} \mathrm{L}^{-1}\right)$ & $1.6 \pm 0.5$ & 2.8 & 1 & $3.1 \pm 0.6$ & 4.5 & 2.5 \\
$\mathrm{TP}\left(\mathrm{g} \mathrm{L}^{-1}\right)$ & $0.7 \pm 0.3$ & 1.3 & 0.3 & $1.2 \pm 0.3$ & 1.8 & 0.7 \\
$\mathrm{~K}\left(\mathrm{~g} \mathrm{~L}^{-1}\right)$ & $1.9 \pm 0.8$ & 3.9 & 1.1 & $2.2 \pm 0.5$ & 3.6 & 1.5 \\
$\mathrm{Cu}\left(\mathrm{mg} \mathrm{L}^{-1}\right)$ & $37 \pm 19$ & 82 & 9 & $31 \pm 12$ & 62 & 11 \\
$\mathrm{Zn}\left(\mathrm{mg} \mathrm{L}^{-1}\right)$ & $303 \pm 147$ & 540 & 43 & $53 \pm 15$ & 90 & 27 \\
$\mathrm{pH}$ & $6.5 \pm 0.1$ & 6.7 & 6.4 & $7.5 \pm 0.3$ & 8.2 & 6.9 \\
\hline
\end{tabular}

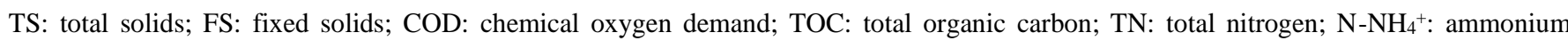
nitrogen; TP: total phosphorus; K: potassium; $\mathrm{Cu}$ : copper; $\mathrm{Zn}$ : zinc; pH: hydrogen potential. Source: Adapted from Tavares (2016).

As shown in Table 2, pig manure has wide variations in the concentration of solids, carbon, $\mathrm{pH}$ and nutrients. This variability in manure makes it difficult to adopt a single treatment or use strategy as fertilizer, which increases the associated environmental risks. Due to its physical characteristics (predominantly in the liquid phase), manure is disposed in soil close to the pig production facilities. As it consists of large amounts of water, it has not been financially attractive to transport manure over long distances. Thus, large amounts of fertilizer are applied to soils of the same areas (Aita et al., 2015) and often above levels foreseen in current legislation. Continued manure application may have positive or negative effects in soil microbial communities. Data from the literature show that areas fertilized with liquid pig manure have higher $\mathrm{N}_{2} \mathrm{O}$ emissions compared to areas using synthetic fertilizers (Decock, 2014). However, these effects are associated to several factors, such as the characteristics of pre-existing microbial communities in soil as well as the management and the physical, chemical and microbiological properties of manure.

Thus, the objectives of this review were: (i) Verify which are the main processes involved in $\mathrm{N}_{2} \mathrm{O}$ emissions in soils fertilized with pig manure; (ii) What are the direct emissions on these soils under different management systems, and; (iii) What are the possible $\mathrm{N}_{2} \mathrm{O}$ emissions control and mitigation strategies.

\section{Methodology}

Regarding the research characteristic, the study has an exploratory and qualitative character (Pereira, 2018). Data recovery was performed in articles published in scientific journals without defining a specific period, using the search tools of the Portal de Periódicos Capes (CAPES / MEC, Brasília, DF, Brazil). Keywords used in the searches included 'óxido nitroso', 'nitrous oxide', ' $\mathrm{N}_{2} \mathrm{O}$ ', 'nitrogênio', 'nitrogen', 'suínos, 'pig, 'swine', 'dejetos', 'manure' and 'slurry'. The publications obtained were imported, and duplicate occurrences were checked, using an EXCEL spreadsheet. To minimize bias, some criteria were applied: (i) emissions measured during the development cycle of agricultural crops in the field, with the development of crops in the soil; (ii) emissions reported in experiments that include treatments with and without nitrogen 
fertilizer application; (iii) $\mathrm{N}$ source of chemical or organic synthesis, and; (iv) areas with and without irrigation. In order to verify the effect of mitigation strategies on $\mathrm{N}_{2} \mathrm{O}$ emissions, studies using slow-release fertilizers, enzyme inhibitors or coated with polymers were considered. The majority of articles published since the 2000 s were recovered, in a total of 85 publications. They were pre-selected for reading and inclusion in this literature review was one that met the selection criteria used. To verify the direct emissions in soils fertilized with swine manure, studies were used in which corn (grains or silage), black oats or wheat were grown, resulting in a total of eight publications.

\section{Main Soil Processes Involved in $\mathrm{N}_{2} \mathrm{O}$ Emissions}

Approximately $70 \%$ of the global soil $\mathrm{N}_{2} \mathrm{O}$ emissions are a result of microbial nitrification and denitrification processes (Syakila and Kroeze, 2011). The metabolic pathways responsible for emissions are extensive, often producing simultaneous $\mathrm{N}_{2} \mathrm{O}$ emission and consumption (Butterbach-Bahl et al., 2013). The addition of chemical or organic fertilizers induces changes in microbial communities (Suleiman et al., 2016), which consequently affect $\mathrm{N}_{2} \mathrm{O}$ emissions. These microorganisms are associated with rhizosphere, soil particles and decomposing organic material, and respond quickly to changes in soil management and fertilization. Thus, they are good indicators of the changes in soil properties. Microbial communities responsible for $\mathrm{N}_{2} \mathrm{O}$ emissions are vast and contain strictly nitrifying organisms and facultative anaerobes. Therefore, it is important to define fertilization strategies according to use and crop. It is important to emphasize that communities modulate their activity according to nutrient, carbon, and oxygen availability, in addition to soil moisture (Meng, Ding, and Cai, 2005).

When applied in both organic forms (e.g., hippuric acid - $\mathrm{C}_{9} \mathrm{H}_{9} \mathrm{NO}_{3}$ ) and free forms (e.g., ammonia - $\mathrm{NH}_{3}$ ), nitrogen compounds in pig manure are used as energy sources by soil organisms, especially by bacteria and archaea. Electron consumption for reducing one atom of $\mathrm{O}_{2}$ to water occurs in the nitrification process (Heil, Vereecken, and Brüggemann, 2016). This produces some intermediates such as hydroxylamine $\left(\mathrm{NH}_{2} \mathrm{OH}\right)$ and nitrite $\left(\mathrm{NO}_{2}^{-}\right)$, generating nitrate $\left(\mathrm{NO}_{3}^{-}\right)$as the final product (Figure 1). 
Figure 1. Schematic representation of the nitrification process.

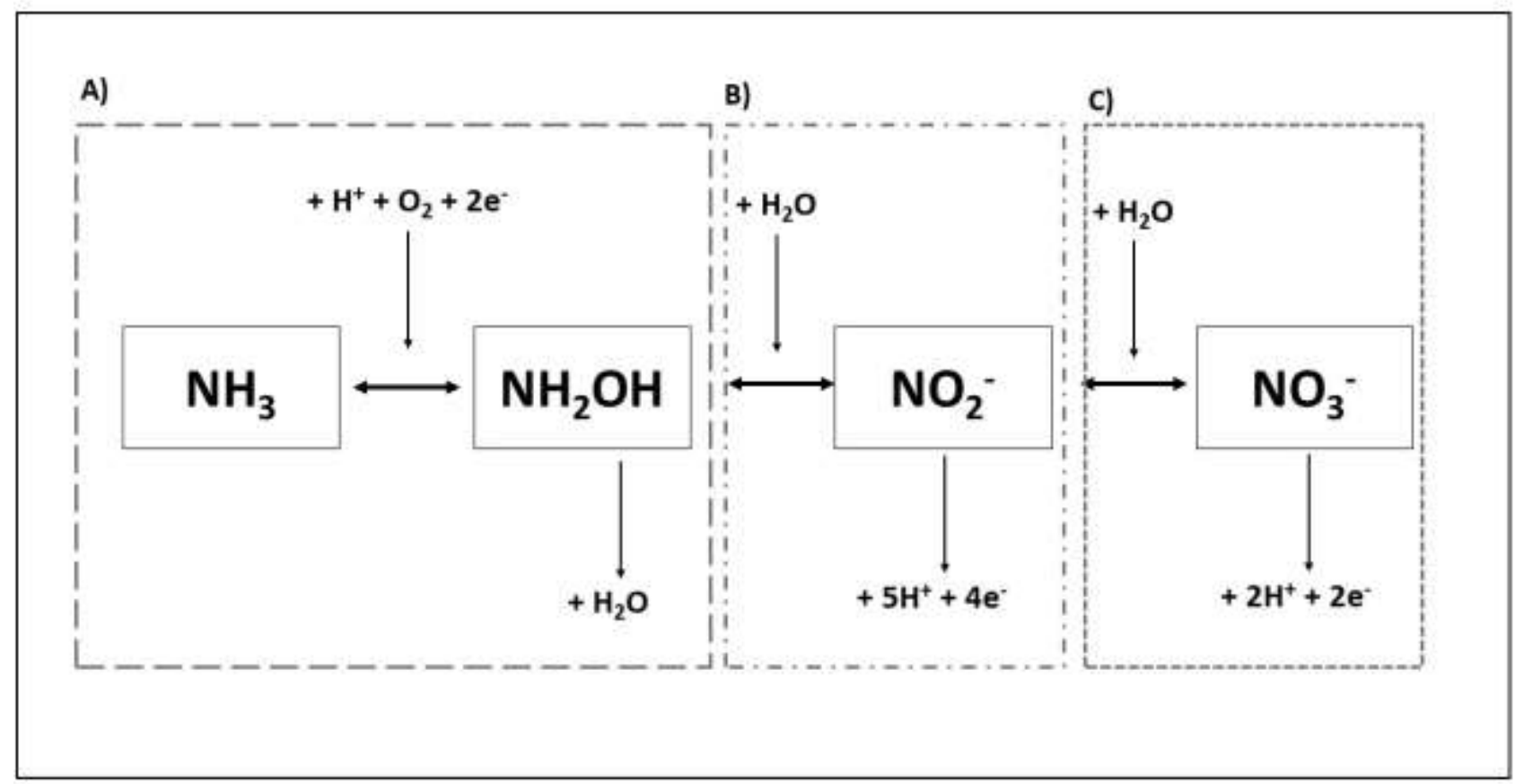

Source: Authors.

In the first stage of the nitrification process the formation energy $\left(\Delta \mathrm{G}^{0}\right.$ ') is positive, that is, the reaction does not occur spontaneously, requiring external energy for it to occur. This energy can be provided by both biotic factors (e.g. microbial activity) and abiotics (e.g. the presence of electrons in the soil solution). Conversion of hydroxylamine $\left(\mathrm{NH}_{2} \mathrm{OH}\right)$ to nitrite $\left(\mathrm{NO}_{2}^{-}\right)$occurs quickly, since the $\Delta \mathrm{G}^{0}$, value of the reaction is negative (spontaneous reaction).

After the oxidation of $\mathrm{NH}_{3}$ to $\mathrm{NO}_{3}{ }^{-}$, it can then be used in other pathways (e.g., uptake by plant and microorganisms). When nitrate is present in the soil solution, it can be used as an electron acceptor by the same autotrophic ammonia-oxidizing bacteria. It is then reduced to nitric oxide (NO) and $\mathrm{N}_{2} \mathrm{O}$ by nitrification-denitrification processes (Figure 2). 
Figure 2. Schematic representation of the denitrification process.

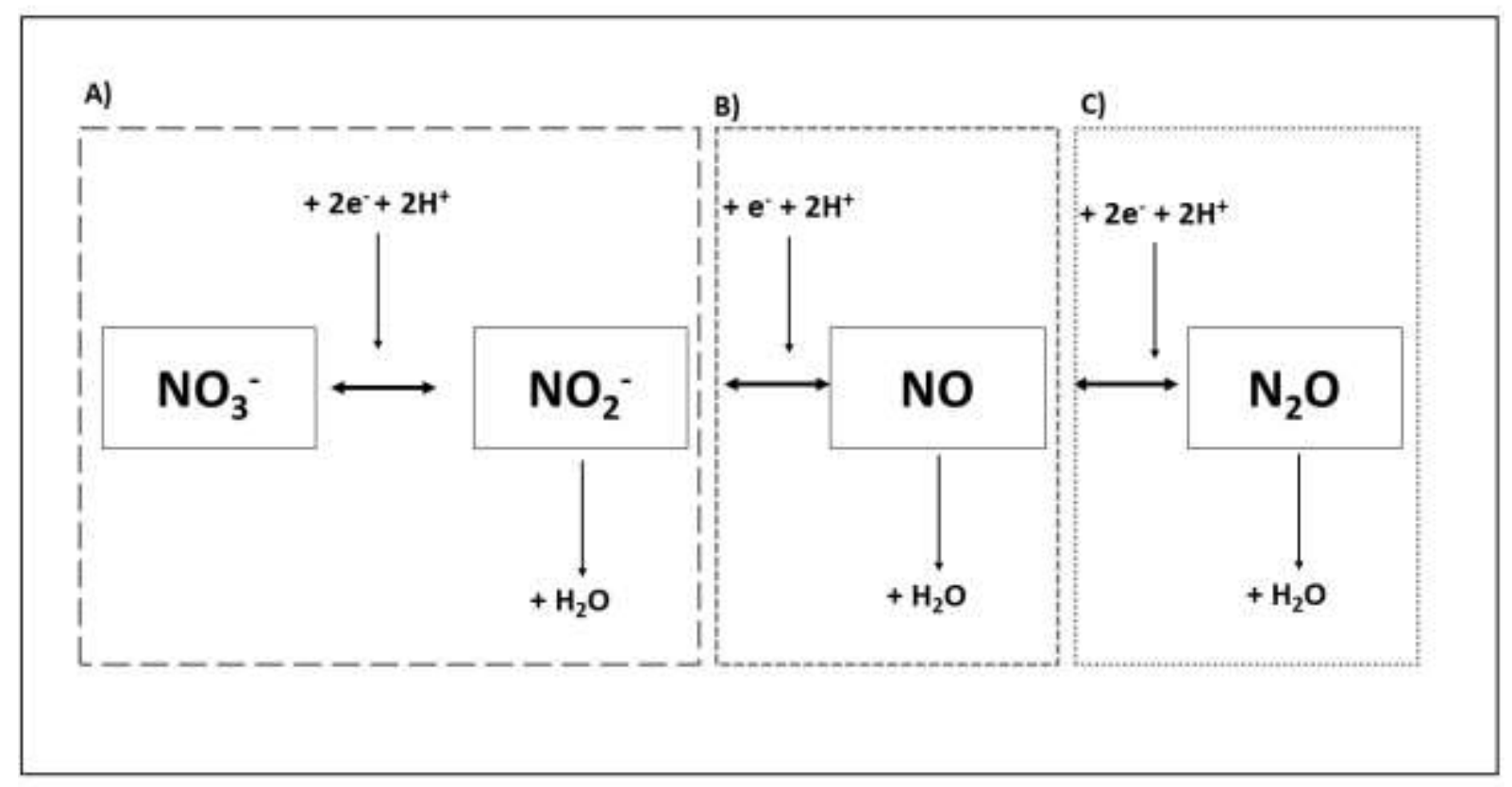

Source: Authors.

When nitrate is present in the soil solution, it can be used as an electron acceptor by the same autotrophic oxidizing bacteria as ammonia. It is then reduced to nitric oxide (NO) and $\mathrm{N}_{2} \mathrm{O}$ by nitrification-denitrification processes (Figure 2). The reduction of nitrate to $\mathrm{N}_{2} \mathrm{O}$ requires electrons and $\mathrm{H}^{+}$ions present in the solution, or supplied by soil microorganisms. A description of the main pathways involved in soil $\mathrm{N}_{2} \mathrm{O}$ emission and consumption is presented below.

\subsection{Biotic denitrification}

Biotic denitrification is a bacterial and fungal respiratory process that occurs under anaerobic conditions, and it is the main source of $\mathrm{N}_{2} \mathrm{O}$ emission. Microorganisms use nitrate, nitrite and soluble nitrogen gases as electron acceptors instead of oxygen (Phillipot et al., 2007). The conversion of soluble nitrogen oxides to $\mathrm{N}_{2} \mathrm{O}$ is catalyzed by enzymes, which are inhibited in the presence of oxygen. Because it is a heterotrophic process, denitrification requires labile sources of carbon as substrate (Butterbach-Bahl et al., 2013).

\subsection{Abiotic denitrification}

Abiotic denitrification occurs predominantly under conditions of high nitrate concentration and in soils with $\mathrm{pH}<5.0$. The chemical decomposition of hydroxylamine and nitrite occurs during nitrification to form $\mathrm{NO}, \mathrm{N}_{2} \mathrm{O}$ and eventually $\mathrm{N}_{2}$. The decomposition of ammonium nitrate may also occur in the presence of light, moisture and reactive surfaces. The importance of this pathway as a source of $\mathrm{N}_{2} \mathrm{O}$ emission is significantly lower compared to the biotic process (Butterbach-Bahl et al., 2013).

In addition to these processes, nitrite may react with several metals in soil, producing gases such as $\mathrm{N}_{2} \mathrm{O}$ through reactions with $\mathrm{Fe}^{+3}$ and $\mathrm{Cu}^{+2}$ ions (Heil, Vereecken, and Brüggemann, 2016).

\subsection{Dissimilatory nitrate reduction}

Nitrate ammonification or dissimilatory reduction of nitrate to nitrite and ammonium (DNRA) is a process conducted by both facultative and obligate anaerobes under strictly anaerobic conditions. This process occurs predominantly in 
hydromorphic soils and its magnitude varies according to the availability and relationship between $\mathrm{C}$ and $\mathrm{N}$ (Butterbach-Bahl et al., 2013).

\subsection{Ammonia oxidation}

The oxidation of ammonia to hydroxylamine and then to nitrite is an autotrophic process, which occurs mainly by the action of bacteria of the genus Nitrosomonas, Nitrosolobus and Nitrospira (associated with acidic soils). In addition to the formation of nitrite $\left(\mathrm{NO}_{2}\right)$, other oxidation products of ammonia are $\mathrm{N}_{2} \mathrm{O}$ and $\mathrm{H}^{+}$ions, generating temporary acidification of the medium as the final product. Under aerobic conditions, $\mathrm{N}_{2} \mathrm{O}$ amounts to less than $1 \%$ of oxidized ammonia and this ratio increases as oxygen availability is reduced (Heil, Vereecken, and Brüggemann, 2016).

\section{Factors Influencing $\mathrm{N}_{2} \mathrm{O}$ Emissions}

The processes that govern nitrogen loss include a complexity of biotic and abiotic factors, as well as management practices, climate and soil properties, which condition the dynamics of nitrogen and carbon in soil. Some of the factors that contribute to the increase of $\mathrm{N}_{2} \mathrm{O}$ emissions are the availability of readily assimilable carbon sources from animal manure and agricultural and cover crop residues, as well as soil carbon.

We will now present how pig farming can influence the processes responsible for soil $\mathrm{N}_{2} \mathrm{O}$ emission. The influencing factors are divided into: (i) pig nutrition, (ii) manure storage and treatment, (iii) manure composition, (iv) heavy metal presence, and (v) oxygen diffusion.

\subsection{Pig nutrition}

Reducing labile nitrogen and carbon contents in excreta by managing animal diet may potentially reduce GHG emissions, especially $\mathrm{N}_{2} \mathrm{O}$. In animal excreta, volatile forms of nitrogen are mainly present in urine (Montes et al., 2013). These nutrients are provided especially (or largely) in protein compounds made available in the diet. Thus, the management of the components and contents of the ingredients in the feed may be an important tool to reduce $\mathrm{N}_{2} \mathrm{O}$ emissions.

$\mathrm{Cu}$ and $\mathrm{Zn}$ are used in pig diet as growth promoters and for the prevention/treatment of diarrhea. The effect of the presence of these metals will be presented and discussed in section 4.4.

\subsection{Manure storage and treatment}

The composting of pig manure is classified as an aerobic treatment. It can be done with passive aeration (natural) or active aeration (oxygen injection). It is an alternative to reduce the volume of manure, facilitating its treatment, transport and disposal to the soil. The addition of carbon-rich material (typically sawdust, shavings or rice husk) reduces the labile fractions of carbon and nitrogen and consequently $\mathrm{N}_{2} \mathrm{O}$ emissions. In evaluating $\mathrm{CH}_{4}$ and $\mathrm{N}_{2} \mathrm{O}$ emissions during the composting process in passive aeration, active aeration and liquid manure storage systems, Thompson, Wagner-Riddle and Fleming (2003) found a reduction of $30 \%$ in the emissions of these gases in active aeration compared to liquid manure storage. On the other hand, the authors found an increase in emissions of approximately $300 \%$ in passive aeration compared to liquid manure storage. Active aeration systems are the most efficient in stabilizing the compost, reducing the anoxic zones and $\mathrm{N}_{2} \mathrm{O}$ emissions (Osada, Kuroda, and Yonaga, 2000).

Lagoons are the most commonly used liquid manure system in Brazil. In legislation of the state of Santa Catarina, hydraulic retention time of manure in lagoons should be the equal to the number of days in which the application of manure to the soil was licensed, and should be no less than 40 days (FATMA, 2014). This period is intended to stabilize and reduce organic matter, reduce pathogens and adsorb phosphorus. The discharge rate of the lagoon is defined based on the availability 
of farm areas suitable for the application of manure and the critical limit of phosphorus. An alternative to lagoons is the use of anaerobic biodigesters. However, the reduction of the organic loading rate through anaerobic treatment in biodigesters has contrasting effects. On the one hand, methane $\left(\mathrm{CH}_{4}\right)$ production occurs through the degradation of part of the organic matter in manure. On the other hand, the degradation of the carbon compounds generates a digest with lower organic loading rate, which may reduce emissions after application in soil. The agronomic value of manure from anaerobic treatment systems reduces emissions at the time of application and throughout the biological transformations occurring in soil (nitrification and denitrification), compared to the raw manure (Dennehy et al., 2017). Additionally, the use of anaerobic treatments is a possible alternative to increase the energy value, reducing the use of fossil fuels and the environmental impacts associated with this energy source, including the emission of greenhouse gases.

In evaluating $\mathrm{N}_{2} \mathrm{O}$ emissions in soil fertilized with pig manure from different treatment systems (separation of solid and liquid phase, untreated and anaerobically treated), Bertora et al., (2008) found a significant decrease in the loss of $\mathrm{N}$ applied to soil as $\mathrm{N}_{2} \mathrm{O}$, in the following order: untreated liquid manure> liquid fraction> anaerobically treated liquid manure> solid fraction. The authors associate such effects to carbon, fiber and $\mathrm{N}-\mathrm{NH}_{4}{ }^{+}$contents in manure.

\subsection{Manure composition: carbon and other nutrients}

Carbon and nutrient contents (mainly nitrogen) in pig manure are one of the main factors that impact the emissions of greenhouse gases after application in soil. Pigs are monogastric animals and compared to polygastric animals produce manure with high proportions of biodegradable carbon (Amon et al., 2007), which is available for soil microbial processes.

On average, $80 \%$ of $\mathrm{N}, 78 \%$ of $\mathrm{P}$ and $95 \%$ of $\mathrm{K}$ present in animal diet are found in raw manure, which depends on the animal species and the diet. In Brazil, manure is applied predominantly in liquid form in which nitrogen is mainly present in ammonium form. Once in the soil, this form of nitrogen is used as substrate for nitrification and denitrification.

\subsection{Heavy metal presence}

The presence of heavy metals promotes a decrease in the genetic diversity of microbial communities. On the other hand, some studies show that the presence of these metals may induce the tolerance of microbial communities over time (Philippot, Hallin, and Schloter, 2007). Nitrification and denitrification are sensitive to environmental changes and are influenced by the presence of soil contaminants. The enzymes that catalyze the reduction reactions are activated by the expression of narG and napA (nitrate reductase), nirK and nirS (nitrite reductase), norB (nitric oxide reductase) and nosZ (nitrous reductase) (Philippot, Hallin, and Schloter, 2007).

Studies in literature show the presence of heavy metals such as zinc $\left(\mathrm{Zn}^{+2}\right)$, nickel $\left(\mathrm{Ni}^{+2}\right)$ and cadmium $\left(\mathrm{Cd}^{+2}\right)$ inhibit the expression of nos $Z$, especially copper $\left(\mathrm{Cu}^{+2}\right)$ (at concentrations $\geq 0.5 \mathrm{mg} \mathrm{L}^{-1}$ ) (Gui et al., 2017). This gene is responsible for the activation of $\mathrm{N}_{2} \mathrm{O}$ reductase, an enzyme that catalyzes the reduction of $\mathrm{N}_{2} \mathrm{O}$ to $\mathrm{N}_{2}$ and is activated by nos $Z$ (Figure 3). 
Figure 3. Schematic representation of the enzymes responsible for the denitrification process.

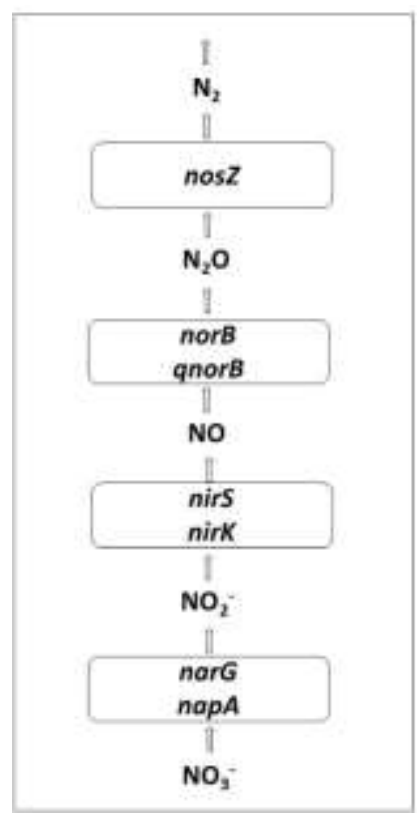

Source: Authors.

The process of reducing $\mathrm{NO}_{3}{ }^{-}$to $\mathrm{N}_{2}$ (dinitrogen) is mediated by enzymes, as described in figure 3 . The inhibition of the nos $Z$ enzyme by the presence of metals such as $\mathrm{Cu}^{+2}$, in the last stage of the biotic denitrification process, resulting in increases in $\mathrm{N}_{2} \mathrm{O}$ emissions to the atmosphere. This phenomenon is likely to occur in areas with a history of surface applications of liquid pig manure. After 32 applications over 10 years, Tiecher et al. (2013) found $\mathrm{Cu}^{+2}$ contents available in the topsoil ( $0.00-0.05 \mathrm{~m})$ varied from 11 to $111 \mathrm{mg} \mathrm{kg}^{-1}$. It is important to note that approximately $90 \%$ of the copper content found in soil is in soluble form (in soil solution), wherein the surface layer approximately $30 \%$ is in the form of $\mathrm{Cu}^{+2}$ and $60 \%$ are bound to dissolved organic compounds (De Conti et al., 2016).

\subsection{Oxygen diffusion}

Oxygen diffusion is associated to soil physical properties, such as structure, texture, and organic matter content, in addition to management practices. Agricultural practices promote soil densification by reducing partial oxygen pressure. Also, with the addition of organic fertilizers in soil, there is increased availability of labile carbon, in addition to nitrogen used as substrate by heterotrophic microorganisms. Thus, the formation of anaerobic microsites occurs by oxygen consumption, generating the necessary conditions for denitrification (Meng, Ding, and Cai, 2005). Denitrification occurs preferentially under conditions water-filled pore space (WFPS, \%) above $80 \%$.

Pig manure of growing-finishing phase presents solids contents of approximately 6\% (Tavares, 2016). Its application on the soil surface may contribute to reduce the diffusivity of oxygen in soil. In evaluating the effect of liquid pig manure application on oxygen diffusion and $\mathrm{N}_{2} \mathrm{O}$ production, Zhu et al. (2015) found a stimulus to the development of anoxic zones and consequently the production of $\mathrm{N}_{2} \mathrm{O}$. This behavior may be associated to the inhibition of the enzymes responsible for the reduction of $\mathrm{N}_{2} \mathrm{O}$ to $\mathrm{N}_{2}$. In addition to the effect of liquid pig manure application, Meijide et al. (2007) found found higher $\mathrm{N}_{2} \mathrm{O}$ emissions after the application of liquid pig manure, coinciding with irrigations in which WFPS was above 70\%. Soil moisture affect the frequency of nirK, norB and nos $Z$ in soil, increasing in the number of copies of nos $Z$. 


\section{Direct Emissions of Soils Fertilized With Pig Manure}

Studies carried out in several regions of the world $(n=8)$ show significant variability in $\mathrm{N}_{2} \mathrm{O}$ emissions, with

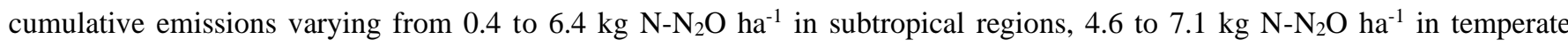

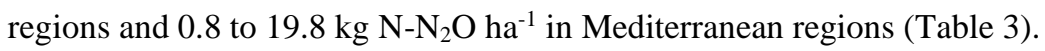

Table 3. Nitrous oxide emissions in areas fertilized with pig manure.

\begin{tabular}{|c|c|c|c|c|c|c|c|c|}
\hline \multirow[t]{2}{*}{ Reference } & \multirow[t]{2}{*}{ Country } & \multirow[t]{2}{*}{ Climate } & \multirow[t]{2}{*}{ Crop } & \multirow[t]{2}{*}{ Source } & \multirow{2}{*}{$\begin{array}{c}\text { Duration } \\
\text { (day) }\end{array}$} & \multirow[t]{2}{*}{ Soil } & \multirow{2}{*}{ 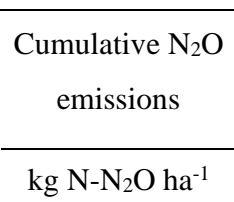 } & $\begin{array}{l}\text { Emission } \\
\text { factor }^{\mathrm{b}}\end{array}$ \\
\hline & & & & & & & & $(\%)$ \\
\hline Giacomini et al., 2006 & Brazil & Subtropical & Black oat & APM & 28 & Sandy clay & 0.4 & 0.2 \\
\hline Gonzatto et al., 2013 & Brazil & Subtropical & Corn & APM & 90 & Sandy clay & 1.2 & nd \\
\hline Gonzatto et al., 2013 & Brazil & Subtropical & Corn & $\mathrm{APM}+\mathrm{OS}$ & 90 & Sandy clay & 3.2 & nd \\
\hline Aita et al., 2015 & Brazil & Subtropical & $\begin{array}{l}\text { Corn- } \\
\text { wheat }\end{array}$ & $\mathrm{APM}+\mathrm{DCD}$ & 357 & Loam & 5.0 & 0.77 \\
\hline Aita et al., 2015 & Brazil & Subtropical & $\begin{array}{l}\text { Corn- } \\
\text { wheat }\end{array}$ & APM & 357 & Loam & 6.4 & 1.36 \\
\hline Chantigny et al., 2010 & Canada & Temperate & Corn & APM & $1095^{\mathrm{a}}$ & Loam & 4.6 & 2.4 \\
\hline Chantigny et al., 2010 & Canada & Temperate & Corn & APM & $1095^{\mathrm{a}}$ & Clayey & 7.1 & 3.1 \\
\hline Dambreville et al., 2008 & France & Mediterranean & Corn & APM & 325 & Silty loam & 0.8 & 0.38 \\
\hline Dambreville et al., 2008 & France & Mediterranean & Corn & LPM & 348 & Silty loam & 1.0 & 1.07 \\
\hline López-Fernández et al., 2007 & Spain & Mediterranean & Corn & LPM & 200 & Sandy loam & 4.6 & 1.02 \\
\hline López-Fernández et al., 2007 & Spain & Mediterranean & Corn & LMPinc & 200 & Sandy loam & 5.1 & 1.27 \\
\hline Meijide et al., 2007 & Spain & Mediterranean & Corn & LPM & 142 & Sandy loam & 8.3 & 1.3 \\
\hline \multirow[t]{2}{*}{ Meijide et al., 2007} & Spain & Mediterranean & Corn & $\mathrm{CPM}+\mathrm{U}$ & 142 & Sandy loam & 9.3 & 1.88 \\
\hline & & Mediterranean & Corn & & & & & 1.82 \\
\hline Louro et al., 2015 & Spain & & silage & LPMinj & 126 & Silty loam & 19.8 & \\
\hline
\end{tabular}

$\mathrm{APM}=$ pig manure after anaerobic treatment; $\mathrm{APM}+\mathrm{OS}=$ pig manure after anaerobic treatment + oat straw; LPM = liquid pig manure; LPMinc $=$ incorporated liquid pig manure; $\mathrm{LPMinj}=$ injected liquid pig manure; $\mathrm{DCD}=$ dicyandiamide; $\mathrm{CPM}+\mathrm{U}=$ pig manure compost + urea; nd $=$ not available.

${ }^{\text {a Approximately. }}$

${ }^{\mathrm{b}}$ Calculated from nitrogen loss of the control treatment (Factor used by the IPCC: 1.25 )

Source: Authors.

The highest emissions of $\mathrm{N}_{2} \mathrm{O}$ seem to be related to soil type (influence of texture), application method (incorporated or injected), manure type (raw or treated), the joint use of manure and chemical fertilization, and the use of nitrification inhibitors. Studies show that emissions are also associated to the effects of soil moisture, carbon and nitrogen in manure, and manure storage time (this reduces contents of easily degradable carbon). Climate and local topographic effects, such as the presence of soils with hydromorphic characteristics also influence emissions. The applicability of global emission factors, such as those proposed by the IPCC (1.25\%), is difficult at regional or local scales.

Internationally, another factor associated with the large variability of $\mathrm{N}_{2} \mathrm{O}$ emission values may be linked to deficient and limited techniques used for measuring emissions. Static chamber is the most currently used method (Butterbach-Bahl et al., 2013). 


\section{Control and Mitigation Strategies}

\subsection{Managing pig nutrition}

One of the strategies for reducing greenhouse gas emissions from animal manure is the management of crude protein levels in feed (Philippe and Nicks, 2015). Sanchez-Martín et al. (2017) evaluated the effect of the addition of fiber sources (consisting of $\mathrm{N}$ ) on the diet of animals to reduce the concentrations of benzoic acid and hippuric acid in manure (feces and urine). The authors found that the addition of fiber sources caused reductions of 47 to $65 \%$ in $\mathrm{N}_{2} \mathrm{O}$ emissions after manure application in soil.

In evaluating the emissions of $\mathrm{N}_{2} \mathrm{O}$ in soil treated with manure from groups of piglets fed with 10 different diets, Velthof et al. (2005) found that regardless of soil texture (clayey or sandy), the lowest emissions were found in soils fertilized with manure from diets with lower protein contents. However, the variation of carbohydrate levels in the diet increased emissions in sandy soil.

\subsection{Manure treatment}

The use of technologies for pig manure treatment is an important strategy for reducing greenhouse gas emissions. Among the strategies that enable the reduction of $\mathrm{N}_{2} \mathrm{O}$ emissions after application to the soil is decreasing the water content of manure, composting and improving anaerobic digestion.

Improving water supply efficiency for housed animals also contributes to reducing emissions after manure application in soil. The reduction of water content in manure through more efficient use of drinkers results in a smaller volume of manure. The use of nipple drinkers can reduce water losses by approximately $19 \%$ and $16 \%$ in comparison to bite-ball nipple and bowl. This was verified by Tavares et al. (2014) in a study carried out in 15 commercial farms in the growing-finishing phase. Thus, manure has higher solids contents (6\% on average) (Tavares, 2016), contributing to the reduction of anaerobic sites in soil. Another alternative for reducing the moisture content in manure is the separation of the solid and liquid phases (Bertora et al., 2008), with subsequent composting of the liquid phase.

Composting of slurry is another alternative for reducing emissions. In evaluating the effect of the addition of liquid pig manure and pig manure compost on the soil, Kariyapperuma, Furon and Wagner-Riddle (2012) found reductions of up to $57 \%$ in soil $\mathrm{N}_{2} \mathrm{O}$ emissions after the addition of treatments.

As for anaerobic digestion, improving the process reduces degradable carbon, energy availability for nitrifying microorganisms, and $\mathrm{N}_{2} \mathrm{O}$ production in soil (Montes et al., 2013).

\subsection{Fertilization strategies}

The highest $\mathrm{N}_{2} \mathrm{O}$ emissions occur mostly after the addition of manure to the soil, which are simultaneous with the peaks of nitrogen availability (Meng, Ding, and Cai 2005; Dambreville, Morvan, and Germon 2008; Gonzatto et al., 2013). Therefore, the addition of slow-release nutrient sources (e.g., pig manure compost or pelleted manure) may be an alternative to delay the processes of nutrient release, especially nitrogen. This promotes improved synchronization between release and the phase of greater crop demand. In addition, split fertilization may be another efficient alternative for reducing $\mathrm{N}_{2} \mathrm{O}$ emissions. Shcherbak, Millar, and Robertson (2014) have shown through meta-analysis that nitrogen fertilization in doses $\leq 50 \mathrm{~kg} \mathrm{~N}^{-1}$ reduce $\mathrm{N}_{2} \mathrm{O}$ emission factor more than the value recommended by the IPCC.

Another efficient alternative is the increased uptake of soil nutrients by crops. Genetic improvement programs for agricultural crops could select cultivars in locations with high nutrient content, thus allowing the development of varieties that will adapt to these conditions. Fertilizers are typically applied with high amounts of nutrients per hectare. This results in 
readily available nutrients, especially nitrogen for the microbial processes responsible for $\mathrm{N}_{2} \mathrm{O}$ emissions, which increase exponentially with increasing nitrogen levels per hectare (Shcherbak, Millar and Robertson, 2014).

The rate at which nitrogen preferentially present as ammonium in liquid manure is converted to nitrate may result in increased $\mathrm{N}_{2} \mathrm{O}$ emissions. When converted to nitrate $\left(\mathrm{NO}_{3}{ }^{-}\right)$, ammonium nitrogen $\left(\mathrm{NH}_{4}{ }^{+}\right)$is used as substrate by the denitrifying bacteria.

The mechanism of nitrification inhibitors is to inhibit the bacteria responsible for the oxidation of $\mathrm{NH}_{4}{ }^{+}$to nitrite $\left(\mathrm{NO}_{2}{ }^{-}\right)$. This will increase the residence time of $\mathrm{NH}_{4}{ }^{+}$in soil and consequently reduce $\mathrm{N}_{2} \mathrm{O}$ and the risks of nitrogen leaching in the soil profile.

One of the most used nitrification inhibitors is dicyandiamide (DCD), which acts on the oxidation of hydroxylamine to $\mathrm{NO}_{2}^{-}$, with a pronounced effect on Nitrosomonas europaea (Zacherl and Amberger, 1990). In evaluating the effect of liquid pig manure application combined with the use of DCD on $\mathrm{N}_{2} \mathrm{O}$ emissions in corn and wheat cultivation in southern Brazil, Aita et al. (2015) found decreases of $60 \%$ when treatments were applied in single dose combined with DCD. Therefore, the use of nitrification inhibitors proves to be an efficient strategy, because it delays the nitrification process and reduces $\mathrm{N}_{2} \mathrm{O}$ emissions (Meijide et al., 2007).

\subsection{Soil and crop residue management}

Soil management associated with crop and cover crop residues is a viable strategy from an agricultural standpoint. In the literature, inconsistent emission values are presented in areas managed under no-tillage and conventional tillage. In a twoyear study, Baggs et al. (2003) found higher $\mathrm{N}_{2} \mathrm{O}$ emissions in soils managed under no-tillage with cereal residues in comparison to conventional tillage. Soils managed under no-tillage showed higher levels of moisture and organic carbon, forming anaerobic microsites that may increase emissions. On the other hand, Giacomini et al. (2006) did not find increased emissions with liquid pig manure applications in soil managed under no-tillage, compared to soil managed under minimum tillage. However, these authors reported that because of surface application in no-tillage, the formation of surface crusts may reduce oxygen diffusion, forming anoxic zones that contribute to emission peaks after rainfall events. Areas managed under no-tillage with less than 10 years of establishment tend to emit more $\mathrm{N}_{2} \mathrm{O}$ than more consolidated systems (Six et al., 2004).

No-tillage combined with the use of cover crops contributes to increased carbon contents in the upper layers of the soil (Ghimire et al., 2017). The contribution of crop residues and their rotation promotes the increase of carbon stocks over the years, resulting in reduced $\mathrm{N}_{2} \mathrm{O}$ and $\mathrm{CO}_{2}$ emissions. The characteristics of crop residues influence the availability of carbon and nitrogen to the soil, and selecting cover crops is a way to reduce $\mathrm{N}_{2} \mathrm{O}$ emissions. Several authors have found lower emissions in soils with addition of grass residues, which present higher $\mathrm{C} / \mathrm{N}$ ratios, and higher lignin and cellulose contents. This increases the half-life $\left(\mathrm{t}^{1 / 2}\right)$ of the residues in the soil and reduces the release of carbon and nitrogen into the soil (Doneda et al., 2012).

The presence of plants during fallow periods can also be an efficient strategy to reduce $\mathrm{N}_{2} \mathrm{O}$ emissions. LópezFernández et al. (2007) evaluated the effect of the presence and absence of corn plants on the magnitude of $\mathrm{N}_{2} \mathrm{O}$ emissions and found reductions of approximately $34 \%$ in treatments fertilized with pig manure on soil with plants in comparison to those without plants.

\subsection{Managing soil biodiversity}

The use of soil management and fertilization techniques that promote unfavorable environmental conditions for denitrifying bacteria is a possible strategy to reduce $\mathrm{N}_{2} \mathrm{O}$ emissions. Management strategies that increase stable carbon forms in the soil, which contribute to increased diameter of soil aggregates, promote the increase of total soil macroporosity (Loss et 
al., 2015). As a result, there are fewer environments with low oxygen diffusivity, which contributes to reducing denitrification zones.

Another strategy is to enrich soil with bacteria capable of mitigating emissions. In analyzing $\mathrm{N}_{2} \mathrm{O}$ production of indigenous microbial communities of incubated soils from Ireland, Sweden and England after soil enrichment with the addition of a strain of Dyadobacter fermentans, Domeignoz-Horta et al. (2016) reported the influence of soil pH values $(r=10.8$; $P<0.01)$ and $\mathrm{C} / \mathrm{N}$ ratio $(r=19.4 ; P<0.01)$ on the ability of the bacterial strain to mitigate $\mathrm{N}_{2} \mathrm{O}$ emissions.

\section{Final Considerations}

Microbiological processes are mainly responsible for $\mathrm{N}_{2} \mathrm{O}$ emissions from the soil into the atmosphere. $\mathrm{N}_{2} \mathrm{O}$ emissions are intensified when soils under natural conditions are converted to agricultural areas. This behavior is directly related to the effect of agricultural practices on the biological processes involved in $\mathrm{N}_{2} \mathrm{O}$ emissions. Management and fertilization practices (e.g., pig manure) modify the biogeochemical nutrient cycles in agroecosystems, changing contents and availability of nutrient forms in soil, thus increasing $\mathrm{N}_{2} \mathrm{O}$ emissions.

Efficient management of animal manure is one alternative to reduce $\mathrm{N}_{2} \mathrm{O}$ emissions. The efficient use of water in animal production facilities and nutritional strategies that reduce nutrient contents in manure should be developed to minimize its pollution potential. The use of conservative soil management systems and the development of organic fertilization strategies that improve nutrient uptake efficiency by crops and increase carbon and nitrogen stocks in soil should be encouraged to reduce emissions.

We find few studies in the literature that address the effect of managing pig nutrition, their reflexes on the characteristics of manure and, consequently, on $\mathrm{N}_{2} \mathrm{O}$ emissions. Therefore, as a suggestion for future research, we recommend integrated studies of the quantitative and qualitative impacts of the levels and sources of nitrogen in the animals' diets on $\mathrm{N}_{2} \mathrm{O}$ emissions after the manure application to the soil. We also recommend studies related to the effects of copper and zinc contents added to the soil via pig manure on enzymes that catalyze the biotic denitrification process in the soil.

\section{Acknowledgments}

We would like to thank Fundação Agricultura Sustentável - AGRISUS (PA No 2234/17), Universal Call MCTI / CNPq No. 01/2016 for the financial support, and CNPq (Process No 140879/2017-0) for granting the Doctoral scholarship to the first author. To CNPq for the granting of research productivity grants to teacher-researchers Jucinei José Comin and Paulo Belli Filho.

\section{References}

Aguilera, E., Luis Lassaletta, A-C., Josette, G., \& Antonio, V. (2013). The potential of organic fertilizers and water management to reduce $\mathrm{N}_{2} \mathrm{O}$ emissions in Mediterranean Climate cropping systems. A Review. Agriculture, Ecosystems and Environment 164: 32-52. 10.1016/j.agee.2012.09.006.

Aita, C. J., Schirmann, S. B., Pujol, S. J., Giacomini, P. Rochette, D. A., Angers, M. H., Chantigny, R., Gonzatto, D. A., \& Giacomini, A. D. (2015). Reducing nitrous oxide emissions from a maize-wheat sequence by decreasing soil nitrate concentration: effects of split application of pig slurry and dicyandiamide. European Journal of Soil Science 66 (2): 359-68. 10.1111/ejss.12181.

Amon, T., Barbara, A., Vitaliy, K, Werner, Z., Karl, M., \& Leonhard, G (2007). Biogas production from maize and dairy cattle manure-influence of biomass composition on the methane yield. Agriculture, Ecosystems and Environment 118 (1-4): 173-82. 10.1016/j.agee.2006.05.007.

Baggs, E. M., M. Stevenson, M., Pihlatie, A. Regar, H., \& Cook, G. C. (2003). Nitrous oxide emissions following application of residues and fertiliser under zero and conventional tillage. Plant and Soil 254 (2): 361-70. 10.1023/A:1025593121839.

Bertora, C., Francesco, A., Laura, Z., Jan, W. G., Gerard, V., \& Carlo, G. (2008). Pig slurry treatment modifies slurry composition, $\mathrm{N}_{2} \mathrm{O}$, and CO ${ }_{2}$ emissions after soil incorporation. Soil Biology and Biochemistry 40 (8): 1999-2006. 10.1016/j.soilbio.2008.03.021. 
Brasil (2014). Estimativas anuais de emissões de gases de efeito estufa. (http://sirene.mcti.gov.br/documents/1686653/1706227/Estimativasd.pdf/0abe2683e0a8-4563-b2cb-4c5cc536c336)

Butterbach-Bahl, K., E. M. Baggs, M. Dannenmann, R. Kiese, and S. Zechmeister-Boltenstern (2013). Nitrous oxide emissions from soils: how well do we understand the processes and their controls? Philosophical Transactions of the Royal Society B: Biological Sciences 368 (1621): $20130122-20130122$. 10.1098/rstb.2013.0122.

Chantigny, M. H., Philippe Rochette, D. A., Angers, Shabtai Bittman, K. B., Daniel Massé, G. B., Nikita, E-H., \& Marc-Olivier, G. (2010). Soil nitrous oxide emissions following band-incorporation of fertilizer nitrogen and swine manure. Journal of Environment Quality 39 (5): 1545. 10.2134/jeq2009.0482.

Dambreville, C., Thierry, M., \& Jean, C. G. (2008). $\mathrm{N}_{2} \mathrm{O}$ emission in maize-crops fertilized with pig slurry, matured pig manure or ammonium nitrate in Brittany. Agriculture, Ecosystems and Environment 123 (1-3): 201-10. 10.1016/j.agee.2007.06.001.

De Conti, L., Carlos, A., Ceretta, P. A. A., Ferreira, C. R., Lourenzi, E. G., Felipe Lorensini, T. L., Tiecher, C. M., Mylena, G. A., \& Gustavo, B. (2016). Soil solution concentrations and chemical species of copper and zinc in a soil with a history of pig slurry application and plant cultivation. Agriculture, Ecosystems and Environment 216. Elsevier B.V.: 374-86. 10.1016/j.agee.2015.09.040.

Decock, C. (2014). Mitigating nitrous oxide emissions from corn cropping systems in the Midwestern U.S.: potential and data gaps. Environmental Science \& Technology 48 (8): 4247-56. 10.1021/es4055324.

Dennehy, C., Peadar, G., Lawlor, Y. J., Gillian, E., Gardiner, S., Xie, L. D., \& Nghiem, X. Z. (2017). Greenhouse gas emissions from different pig manure management techniques: A Critical Analysis. Frontiers of Environmental Science \& Engineering 11 (3), 11. 10.1007/s11783-017-0942-6.

Domeignoz-Horta, L. A., M. Putz, A. Spor, D. Bru, M. C. Breuil, S., \& Hallin, L. P. (2016). Non-denitrifying nitrous oxide-reducing bacteria - An effective $\mathrm{N}_{2} \mathrm{O}$ sink in soil. Soil Biology and Biochemistry 103 (December): 376-79. 10.1016/j.soilbio.2016.09.010.

Doneda, A., Celso, A., Sandro, J. G., Ezequiel, C. C. M., Diego, A. G., Janquieli, S., \& Rogério, G. (2012). Fitomassa e decomposição de resíduos de plantas de cobertura puras e consorciadas. Revista Brasileira de Ciencia do Solo 36 (6): 1714-23. 10.1590/S0100-06832012000600005.

Dunmola, A. S., M. Tenuta, A. P. Moulin, P., \& Yapa, D. A. L. (2010). Pattern of greenhouse gas emission from a prairie pothole agricultural landscape in Manitoba, Canada. Canadian Journal of Soil Science 90: 243-56. 10.4141/CJSS08053.

FAO (2016). Nitrous oxide emissions in manure management and Manure applied to soils. (http://www.fao.org/faostat/en/\#data)

FATMA (2014). Instrução Normativa $N^{o} 11$ - suinocultura. (http://www.fatma.sc.gov.br/ckfinder/userfiles/arquivos/ins/11/IN\%2011\%20Suinocultura.pdf) (accessed Jun 2017)

Ghimire, R., Urszula, N., Prakriti, B., Augustine, K. O., \& Jay, B. N. (2017). Soil organic matter, greenhouse gases and net global warming potential of irrigated conventional, reduced-tillage and organic cropping systems. Nutrient Cycling in Agroecosystems 107 (1): 49-62. 10.1007/s10705-016-9811-0.

Giacomini, S. J., Claúdia, P. J., Celso, A., Segundo Sacramento Urquiaga, and Bruno José Rodrigues Alves (2006). Emissão de óxido nitroso com a aplicação de dejetos líquidos de suínos em solo sob plantio direto. Pesquisa Agropecuaria Brasileira 41 (11): 1653-61. 10.1590/S0100-204X2006001100012.

Girotto, E., et al (2010). Acúmulo e formas de cobre e zinco no solo após aplicações sucessivas de dejeto líquido de suínos. Revista Brasileira de Ciência do Solo 34 (3): 955-65. 10.1590/S0100-06832010000300037.

Gonzatto, R., et al (2013). Volatilização de amônia e emissão de óxido nitroso após aplicação de dejetos líquidos de suínos em solo cultivado com milho. Ciência Rural 43 (9): 1590-96. 10.1590/S0103-84782013000900009.

Gui, M., et al (2017). Effects of heavy metals on aerobic denitrification by strain Pseudomonas Stutzeri PCN-1. Applied Microbiology and Biotechnology 101 (4). Applied Microbiology and Biotechnology: 1717-27. 10.1007/s00253-016-7984-8.

Heil, J., H., \& Vereecken, N. B. (2016). A review of chemical reactions of nitrification intermediates and their role in nitrogen cycling and nitrogen trace gas formation in soil. European Journal of Soil Science 67 (1): 23-39. 10.1111/ejss.12306.

IPCC (2013). Climate Change 2013: The Physical Science Basis. Climate Change 2013: The Physical Science Basis, no. January 2014: 1-169. $10.1017 /$ СBO9781107415324.

Jongbloed, Age W. 2008. Environmental pollution control in pigs by using nutrition tools age. Revista Brasileira de Zootecnia 37: 215-29.

Kariyapperuma, K. A., et al (2012). Non-growing season nitrous oxide fluxes from an agricultural soil as affected by application of liquid and composted swine manure. Canadian Journal of Soil Science 92 (2): 315-27. 10.4141/cjss2011-059.

López-Fernández, S., J. A. Díez, P. Hernáiz, A. Arce, L. \& García-Torres, A. V. (2007). Effects of fertiliser type and the presence or absence of plants on nitrous oxide emissions from irrigated soils. Nutrient Cycling in Agroecosystems 78 (3): 279-89. 10.1007/s10705-007-9091-9.

Loss, A., et al (2015). Carbono orgânico total e agregação do solo em sistema de plantio direto agroecológico e convencional de cebola. Revista Brasileira de Ciencia do Solo 39 (4): 1212-24. 10.1590/01000683rbcs20140718.

Louro, A., et al (2015). Nitrous oxide emissions from forage maize production on a humic cambisol fertilized with mineral fertilizer or slurries in Galicia, Spain. Geoderma Regional 5: 54-63. 10.1016/j.geodrs.2015.03.004.

Meijide, A., et al (2007). Nitrogen oxide emissions from an irrigated maize crop amended with treated pig slurries and composts in a Mediterranean Climate. Agriculture, Ecosystems and Environment 121 (4): 383-94. 10.1016/j.agee.2006.11.020. 
Meng, L., Weixin, D., \& Zucong, C. (2005). Long-term application of organic manure and nitrogen fertilizer on $\mathrm{N}_{2} \mathrm{O}$ emissions, soil quality and crop production in a sandy loam soil. Soil Biology and Biochemistry 37 (11): 2037-45. 10.1016/j.soilbio.2005.03.007.

Montes, F, R., Meinen, C., Dell, A., Rotz, N., Hristov, J., Oh, G., Waghorn, et al., (2013). SPECIAL TOPICS -- Mitigation of methane and nitrous oxide emissions from animal operations: III. A review of animal management mitigation options. Journal of Animal Science 91: 5070-94. 10.2527/jas2013-6584.

Osada, T, K., \& Kuroda, M. Y. (2000). Determination of nitrous oxide, methane, and ammonia emissions from a swine waste composting process. Journal of Material Cycles and Waste Management, 51-56. 10.1007/s10163-999-0018-1.

Pereira A. S., et al. (2018). Metodologia da pesquisa científica. UFSM. https://repositorio.ufsm.br/bitstream/handle/1/15824/Lic_Computacao_MetodologiaPesquisa-Cientifica.pdf?sequence $=1$

Philippe, F., \& Nicks, B (2015). Review on greenhouse gas emissions from pig houses : production of carbon dioxide , methane and nitrous oxide by animals and manure. Agriculture, Ecosystems and Environment 199: 10-25.

Philippot, L., et al (2007). Ecology of denitrifying prokaryotes in agricultural soil. Advances in Agronomy 96 (January): 249-305. 10.1016/S00652113(07)96003-4.

Sanchez-Martín, L. A., et al (2017). Diet management to effectively abate $\mathrm{N}_{2} \mathrm{O}$ emissions from surface applied pig slurry. Agriculture, Ecosystems and Environment 239 (3): 1-11. 10.1016/j.agee.2016.12.007.

Shcherbak, I., N., \& Millar, G. P. R. (2014). Global metaanalysis of the nonlinear response of soil nitrous oxide $\left(\mathrm{N}_{2} \mathrm{O}\right)$ emissions to fertilizer nitrogen. Proceedings of the National Academy of Sciences 111 (25): 9199-9204. 10.1073/pnas.1322434111.

Six, J., et al (2004). The potential to mitigate global warming with no-tillage management is only realized when practised in the long term. Global Change Biology 10 (2): 155-60. 10.1111/j.1529-8817.2003.00730.x.

Suleiman, A. K.A., et al (2016). Temporal variability of soil microbial communities after application of dicyandiamide-treated swine slurry and mineral fertilizers. Soil Biology and Biochemistry 97: 71-82. 10.1016/j.soilbio.2016.03.002.

Syakila, A., \& Kroeze, C. (2011). The global nitrous oxide budget revisited. Greenhouse Gas Measurement and Management 1 (1): 17-26. 10.3763/ghgmm.2010.0007.

Tavares, J. M.R., et al (2014). The water disappearance and manure production at commercial growing-finishing pig farms. Livestock Science 169 (C). Elsevier: 146-54. 10.1016/j.livsci.2014.09.006.

Tavares, J. M. R. (2016). Modelagem do consumo de água, produção de dejetos e emissão de gases de efeito estufa e amônia na suinocultura. Tese Doutorado, UFSC, Florianópolis, Brasil.

Thompson, A. G, \& Fleming, R. (2003). Emissions of $\mathrm{N}_{2} \mathrm{O}$ and $\mathrm{CH}_{4}$ during the composting of liquid swine manure. Environmental Monitoring and Assessment, 87-104.

Tiecher, T. L., et al. (2013). Forms and accumulation of copper and zinc in a sandy typic hapludalf soil after long-term application of pig slurry and deep litter. Revista Brasileira de Ciência do Solo 37 (3): 812-24. 10.1590/S0100-06832013000300028.

Velthof, G. L., et al (2005). Gaseous nitrogen and carbon losses from pig manure derived from different diets. Journal of Environmental Quality 34: 698-706. $10.2134 /$ jeq2005.0698.

Zacherl, B., \& Amberger, A. (1990). Effect of the nitrification inhibitors Dicyandiamide, Nitrapyrin and Thiourea on Nitrosomonas europaea. Fertilizer Research 22 (1): 37-44. 10.1007/BF01054805.

Zhu, K., et al (2015). Heterogeneity of O2 dynamics in soil amended with animal manure and implications for greenhouse gas emissions. Soil Biology and Biochemistry 84: 96-106. 10.1016/j.soilbio.2015.02.012. 